\title{
Autoriti Sanad Tarekat dan Peranannya dalam Ilmu Tasawuf
}

\author{
The Authority of Chain of Transmission and Its Role in Sufism
}

\author{
FAUDZINAIM BADARUDDIN* \& MUHAMMAD KHAIRI MAHYUDDIN ${ }^{1}$
}

\begin{abstract}
Sanad or silsilah in Sufism occupies an important place in the practice of sufi path (tariqah). It forms as a basic element wherein the practice of sufi path is built upon. The sanad of sufi path refers to the chain transmission which shows a continuous spiritual chain which provides a connection of a sufi teacher to a list of his shuyukh or predecessors. It occupies an important position in the sufi path. Nonetheless, the existent of sufi sanad has been challenged and its validity has been compared to a sanad in hadith transmission. Hence, this article aims to give an explanation on the existent and validity of chain of transmission of sufi sanad and to provide an exposition of its statue and its roles in practical sufism. The writing of this article used a document analysis as its method of collecting data and analysed using a descriptive analysis. This article shows that the sanad of sufi path stands as an integral part of religion itself. It has its authority within the Islamic spiritual culture and plays an important role in an organized tariqah as providing a standard of legitimization and recognition of a sufi to become a teacher or spiritual guide to sufi aspirants.
\end{abstract}

Keywords: Sufi path, sufism, sanad barzakhi, role, authority

Tarekat sufi merupakan istilah yang wujud dalam ilmu tasawuf dan mewakili aspek pengamalan dan pentarbiahan kerohanian Islam. Kewujudan institusi tarekat sufi bermula sebagai suatu kaedah yang disusun secara teratur and terfokus oleh para masha'ikh tasawuf untuk melatih dan mendidik jiwa manusia kembali kepada fitrah penciptaannya. Namun demikian, sejarah perkembangan tarekat sufi turut memaparkan cabaran dan persepsi negatif di kalangan sebahagian masyarakat Islam sendiri terhadapnya. Tarekat sufi dari segi ilmu dan amalan didakwa bukan berasal dari ajaran Islam dan terpengaruh dengan doktrin syiah, batiniah, falsafah dan ajaran agama lain seperti Kristian, Buddha dan Hindu.

Wujud juga anggapan bahawa tarekat sufi adalah satu aliran dan amalan yang terpisah dari perbahasan ilmu-ilmu Islam lain seperti tauhid dan feqah dan sebagainya. Amalan tarekat sufi juga dikaitkan dengan ilmu kebatinan tanpa syariat dan ajaran sesat. Di sebalik tentangan yang dihadapkan kepada pengamalan insitusi tarekat ini, ia masih bertahan dan berkembang dalam masyarakat Islam. Sekalipun demikian, ia tidak bererti bahawa ia bebas daripada kritikan sebahagian sarjana Islam. Antara elemen dalam institusi tarekat yang dipersoalkan golongan salafi ialah aspek sanad atau silsilah. Oleh itu, perbincangan mengenai kewujudan dan kedudukan sanad tarekat perlu diberikan perhatian agar sebuah perspektif yang sahih berpaksi mazhab ahli Sunnah wal-Jamaah dapat diberikan.

${ }^{1}$ Faudzinaim Badaruddin, Ph. D.* (Corresponding author) Assoc. Professor at Centre of Research for Theology and Philosophy, Faculty of Islamic Studies, Universiti Kebangsaan Malaysia, 43600 Bangi, Selangor, MALAYSIA. Email: fnaim@ukm.edu.my; Muhammad Khairi Mahyuddin, Ph. D., Assoc. Professor at the Faculty of Da`wah and Leadership, Universiti Sains Islam Malaysia, 71800 Nilai, Negeri Sembilan, MALAYSIA. Email: muhdkhairi@usim.edu.my https://doi.org/10.24035/ijit.20.2021.208 


\section{Tarekat Menurut Bahasa dan Istilah}

Tarekat sufi bukanlah sesuatu ajaran tambahan baru dalam tasawuf. Tokoh-tokoh ulama tasawuf seperti al-Sirhindi (t.th.), al-Kurdi (1994), Wan Sulaiman (1343H) menyatakan tarekat merupakan intipati ibadah yang berfungsi untuk mendapatkan kehadiran dan ingatan berterusan di dalam hati kepada Allah dalam seluruh ibadah. Perkataan tarekat (Ar. al-tariqah) adalah diambil daripada kalimah Arab 'taraqa'. Kata nama mufradnya ialah tariqatan atau tarekat, manakala kata jamaknya ialah turuq dan tara'iq.

Perkataan tariqah disebut di dalam al-Quran dan hadis dengan beberapa bentuk wazan yang boleh membawa kepada pengertian yang luas. Dari segi bahasa, perkataan tarekat mengandungi beberapa pengertian, iaitu jalan, cara, metod, sistem, aliran, haluan, tempat lalu, goresan, garis, hal, perjalanan ta'ifah sufiyyah, tingkatan, tradisi, kebiasaan, jalan untuk mencapai kebenaran (dlm tasawuf), ilmu tasawuf, ilmu sufi (suluk), tatatertib hidup (mengikut peraturan agama atau ilmu kebatinan), perkumpulan penuntut ilmu tasawuf (al-Mu'jam al-Wasit t.th; Kamus Dewan 2015; Muhammad Idris 1994: Ali Ma'shum et. al.1997; al Bustani 1986).

Dari sudut istilah pula, perkataan al-tariqah ini diberikan takrifan yang berbeza-beza menurut para ulama sufi dan pengkaji ilmu tasawuf berdasar pelbagai sudut fenomena, perihal pengalaman dan ciri ciri tarekat. al-Qashani (1991) menerangkan bahawa al-tariqah ialah alsirah (jalan) yang khusus bagi al-salikin (orang-orang yang berjalan) menuju Allah merentangi berbagai rintangan dan melalui peningkatan berbagai al-maqamat. Al-Jurjani (1985) menjelaskan bahawa al-tariqah ialah perjalanan khusus bagi orang-orang yang menuju kepada Allah dengan mengharungi pelbagai rintangan dan peningkatan rohani dalam pelbagai maqam.

Al-Kurdi (1984) menghuraikan tarekat ialah pengamalan yang selari dengan syariat Islam, berpegang dengan `azimah dan menjauhi sifat mengambil mudah (tasahul) dalam beramal seperti menjauhi segala perkara yang dilarang secara zahir dan batin, menjunjung segala perintah dengan kemampuan yang ada atau menjauhi perkara yang diharam dan dibenci, berlebihan dalam perkara mubah (harus), menunaikan segala kewajipan dan sunat-sunat dengan segala kemampuan di bawah bimbingan seorang `arifyang telah mencapai peringkat rohani yang tinggi.

Al-Shàrani (t.th.) pula mendefinasikan al-tariqah sebagai jalan untuk beramal dengan kandungan syariat Islam. Ia adalah intipati tersembunyi dalam syariat Islam seumpama pati dalam susu. Shaykhul Islam Negeri Kedah, Wan Sulaiman (1352H) pula menjelaskan bahawa tarekat sebagai pengamalan dan ibadah yang selari dengan syariat Islam yang suci. Imran Abu 'Amr (1980) memberi takrif tarekat ialah jalan atau pertunjuk dalam melaksanakan sesuatu ibadah sesuai dengan ajaran yang dibawa oleh Rasulullah dan yang ditunjuk oleh Baginda serta dikerjakan oleh para sahabatnya, tabi'in, tabi tabi'in dan tersusun turun temurun sampai kepada guru-guru dan para ulama secara bersambung sehingga pada masa ini.

Berdasarkan beberapa pengertian tarekat dari segi bahasa dan istilah di atas, dapat disimpulkan bahawa perkataan tarekat sufi boleh didefinisikan secara khusus sebagai jalan pengamalan dan pengibadatan yang mempunyai kaifiyat-kaifiyat, adab-adab, rukun-rukun dan syarat-syarat tertentu secara tersusun diambil daripada al-Quran dan al-Sunnah, ditarbiah oleh seorang Shaykh Murabbi Murshid yang bersambung susur galur silsilah perguruannya hingga kepada Rasullulah, bertujuan untuk menyucikan hati melalui pelbagai pengalaman, rintangan, peningkatan limpahan rohani bagi mencapai kesempurnaan segala perintah agama Islam secara menyeluruh zahir dan batin bagi mencapai rasa sebenar perhambaan diri kepada Allah dan fungsi sebagai KhalifahNya

Huraian di atas menunjukkan bahawa tarekat sufi merupakan wadah dan wahana yang dibangunkan oleh para tokoh sufi hasil pengalaman mereka dalam menghayati ajaran Islam. Justeru institusi tarekat sufi di dunia Islam memainkan beberapa peranan penting dan strategik dalam pembangunan kerohanian umat Islam. Pertama, untuk memelihara nilai dan sifat insaniyyah manusia supaya berada dalam fitrah Islam untuk dapat mencapai makan kehambaan (ubudiyyah) kepada Allah dan peranan KhalifahNya di muka bumi ini dengan senantiasa menjunjung segala perintah-Nya dan menjauhi segala larangan-Nya dengan hati yang ikhlas. Kedua, menyucikan hati daripada segala sifat mazmumah seperti takabbur, riya', ujub dan 
sebagainya. Sifat-sifat madhmudah tersebut merupakan penyakit yang boleh merosakan amal ibadah. Kemudian menghiasi hati dengan sifat mahmudah seperti ikhlas, sabar, takut dan muraqabah.

Ketiga, melatih diri untuk senantiasa ingat kepada Allah natijah dari sentiasa berzikir kepada Allah menjadikan diri mudah dan suka beramal salih seperti yang telah dituntut dalam syariat Islam sehingga diri tidak merasa berat dan susah dalam melaksanakanya atau meninggalkannya. Keempat, dapat merasai dan menghayati secara zawqiyyah kebenaran pengamalan syariat dan mendalami kehalusan keimanan dan makrifah Allah dengan penuh yakin, bersih daripada sebarang unsur syirik samaada yang tersembunyi ( $k h a f i$ ) atau nyata (jali). Kelima, membangunkan dunia dengan syariat Islam melalui hati yang bersih dan saling tolong menolong dalam menyempurnakan perintah agama.

Berdasarkan fakta yang diambil dari al-Quran dan al-Hadis serta sejarah tokoh-tokoh tasawuf Islam, maka amalan tarekat bukanlah suatu rekaan atau kesengajaan yang diada-adakan oleh para ulama tarekat. Dari sudut amalan tarekat, amalan berzikir seperti tahlil, bertasbih, berkhulwah, membaca kitab-kitab Allah secara tadabbur dan penghayatan sifat-sifat mahmudah seperti taubah, muraqabah, harap, takut, bermunajat, zuhud, merendah diri dan sebagainya boleh didapati daripada al-Quran dan al-Hadis. Nabi Muhammad pula banyak menunjukkan contohcontoh ibadat yang menjadi sandaran amalan tarekat sebelum dan selepas nubuwwahnya seperti amalan khulwah di gua Hira dan banyak melakukan ibadat sunat seperti puasa, solat tahajjud dan banyak beristighfar.

Pada zaman Nabi Muhammad, terdapat satu golongan ahli ibadat dan ahli ilmu yang digelar sebagai ahl al-sufah. Golongan ini merupakan kumpulan yang tinggal di Masjid Nabi di mana aktiviti seharian mereka adalah bekerja di siang hari dan beribadat pada malamnya. AlAsfahani (t.th.) mencatatkan lima puluh satu nama Ahl al-Sufah termasuklah Abu Hurayrah, Abu Dhar al-Ghiffari, Salman al-Farisi, Bilal bin Rabah, Ka`ab bin Malik al-Ansari dan Wathilah bin Asqa'. Bagaimanapun, istilah ahl al-sufah ini tidak begitu terkenal kerana generasi ini lebih masyhur dengan istilah al-sahabah disebabkan keistimewaan mereka melihat, melazimi dan mencontohi Baginda dalam beribadah dengan hati yang bersih dalam kehidupan mereka.

Oleh itu, amalan-amalan tarekat tasawuf yang dicontohkan oleh Nabi Muhammad pada abad pertama Hijrah itu pada hakikatnya dikenali sebagai al-ihsan berdasarkan hadis Jibril yang menyentuh persoalan al-Iman, al-Islam dan al-Ihsan. Al-Ihsan ialah maqam ubudiyyah yang tinggi dan bersih dari segala unsur kesyirikan kepada Allah. Ia adalah intipati agama Islam yang bersendikan akidah Islamiyyah yang sahih dan pengamalan syariat yang benar. Bahkan, ihsanlah yang menjadi sifat yang menyempurnakan kedua-dua aspek tersebut.

Perbahasan yang mempertikaikan kewujudan tarekat sufi sebagai sebuah institusi kerohanian Islam yang berasal daripada ajaran Islam perlu diletakkan pada batas yang wajar iaitu perbezaan tarekat sebagai sebuah istilah dengan instusi tarekat sebagai himpunan amalanamalan yang berdasarkan ajaran Islam. Penolakan atau penafian terhadap istilah tarekat (altariqah) sebagai sebuah istilah khusus tidak seharusnya membawa kepada pengingkaran terhadap amalan-amalan yang wujud dalam organisasi tarekat yang telah dipastikan kebenarannya dan sabit serta sahih daripada sumber wahyu. Shaikh Abdul Wahab al-Sha'rani menegaskan bahawa pengingkaran amalan sufi yang benar daripada al-Quran dan al-Sunnah boleh merosakkan iman seorang Muslim (Abdul Samad t.th.).

Selepas kewafatan Baginda, para Sahabat menyambung penyampaian ajaran Islam secara lisan kepada generasi tabiin. Tradisi lisan ini merupakan kaedah yang amat penting untuk memantapkan kefahaman dan menjalinkan hubungan kerohanian serta limpahan keberkatan daripada para guru kepada murid mereka. Pada akhir kurun ke 3 Hijrah/11 Masihi, amalanamalan tasawuf mula diterap melalui kaedah tarekat oleh beberapa tokoh ulama sufi dan disusun menjadi menjadi satu sistem atau aliran pengamalan dan latihan rohani. Pada zaman ini, beberapa kumpulan bersifat gerakan tarekat khusus mula tersebar dalam masyarakat Islam. Antara yang disebut oleh al-Hujwiri ialah al-Muhasibiyyah dinisbahkan kepada Abu Abdullah alHarith bin Asad al Muhasibi, al-Tayfuriyyah dinisbahkan kepada Abu Yazid Tayfur bin Isa alBistami. Pada kurun ke $5 \mathrm{H}$ dan selepasnya, aliran-aliran tarekat telah tumbuh dan https://doi.org/10.24035/ijit.20.2021.208 
diperkemaskan lagi menjadi sebuah institusi rohani yang tersusun dan sistematik dengan pelbagai nisbah berdasarkan nama dan pengalaman rohani masha'ikh tasawuf yang menyusunnya dengan gaya perlaksanaan yang berbeza-beza tetapi mempunyai matlamat yang sama seperti Tarekat Qadiriyyah, Shaziliyyah, Naqshabandiyyah dan lain lain (Jahid 1997).

\section{Kedudukan Sanad Tareqat Sufi}

Sebuah kumpulan itu dikategorikan sebagai tarekat sufi apabila ia memiliki beberapa kriteria penting (Moh. Isom Mudin 2015; Wan Saleha et. al. 2020). Pertama, guru atau Shaykh murshid. Kedua, mempunyai murid yang menuntut atau dipanggil salik atau mubtadi'. Ketiga, mempunyai amalan-amalan rutin, adab-adab dan syarat-syarat tertentu seperti zikir, wirid, hizib dan lain-lain lagi. Keempat, mempunyai tempat suluk, ribat, zawiyyah. Antara empat kriteria ini, shaykh murshid merupakan sumber utama kepada kewujudan sebuah tarekat kerana mustahil sebuah tarekat sufi boleh wujud tanpa seorang guru atau shaykh.

Sanad berasal dari kalimah Arab sanada, yasnudu bererti sandaran, tempat bersandar, tempat berpegang, sokongan, yang dipercaya dan yang sah. Dalam erti kata lain, sanad merujuk kepada tempat sandaran dan sumber asal menentukan kebenaran atau kepalsuannya sesuatu sama ada perkataan, amalan atau ilmu. 'Abd Allah ibn Mubarak mengatakan bahawa jika tiada ilmu sanad maka orang boleh mengatakan apa yang dia suka (law la al-isnad laqala man sha'a ma sha'a), malah mendapatkan sanad yang bersambung itu adalah agama (talab al-isnad al-muttasil min al-din). Perkara yang sama juga ditegaskan oleh Muhammad b. Sirin dengan katanya: "Sesungguhnnya ilmu ini adalah daripada agama. Maka lihatlah dengan siapa kamu mengambil agamamu." Justeru itu, usaha untuk mempunyai dan menjaga sanad merupakan suatu tuntutan yang bersifat fardu kifayah (Sa`ad 2010).

Secara umumnya sanad adalah keistimewaan yang ada pada umat Nabi Muhammad untuk menjaga kemulian dan kebenaran agama Islam daripada sebarang penyelewangan golongan ahli bidaah. Justeru sanad adalah penting dalam proses pemindahan ilmu-ilmu Islam bagi setiap generasi umat Islam. Kewujudan sanad tidak terhad pada bidang periwayatan hadis sahaja. Bahkan sanad juga digunakan dalam pewarisan ilmu- ilmu Islam lain seperti ilmu akidah, ilmu fekah, ilmu tasawuf, ilmu qiraat dan lain-lain.

Berhubung dengan perkara ini, para ulama Islam telah menulis beberapa karya yang menghimpunkan sanad ilmu-ilmu Islam seperti Shaykh al Sayyid Muhammad bin Ali al al-Sanusi (w.1287H) dalam kitabnya, al-Manhal al-Rawi al-Ra'iq fi Asanid al-'Ulum wa Usul al-Tara'iq dan Shaykh Abi Abdullah b Muhammad Saghir al-Fasi (w 1334H) dalam al-Manh al-Badiyyah fi alAsanid al-'Aliyyah wa al-Musalsalat al-Zahiyyah wa al-Turuq al-Hadiyah al-Kafiyyah. Sanad khusus dalam ilmu fekah Shafi iyyah, contohnya, ialah Muhammad b Idris al-Shafi i, daripada Imam Malik b. Anas, daripada Nafi' daripada 'Abd Allah b 'Umar daripada Nabi Muhammad (al-Fasi 2005)

Dalam konteks ilmu tasawuf, perkataan sanad turut digunakan di samping dua istilah lain iaitu al-silsilah dan al-nisbah. Semua istilah itu merujuk kepada sandaran, asal usul dan persambungan rangkaian hubungan para masha ikh tarekat yang tertentu yang memimpin satu generasi ke satu generasi sehingga kepada sahabat dan Nabi. Jadi sanad dalam tarekat sufi lebih merujuk kepada silsilah perguruan, didikan kerohanian dan pemindahan ilmu, amalan dan ehwal kerohanian dari seorang guru yang bersambung silsilahnya kepada Nabi terhadap kerohanian anak muridnya. Sanad tarekat sufi ini adalah berbeza daripada sanad atau silsilah hadis.

Sanad dalam ilmu hadis bererti ikhbar, yakni jalan untuk mengetahui matan atau teks hadis. Terdapat juga sebahagian ulama hadis menyatakan bahawa sanad adalah jalur atau silsilah yang menyampaikan seseorang kepada matan hadis atau dengan kata lain urutan beberapa nama yang meriwayatkan hadis daripada seorang perawi kepada perawi yang lain sehingga sampai kepada Nabi Muhammad. Sementara itu isnad diartikan sebagai penisbahan sebuah hadis kepada orang yang menyampaikannya (Zaidan 2008: 47; Tahhan 1991:16). Secara umumnya, kriteria utama penerimaan periwayatan sesebuah hadis sebagai sahih atau sebaliknya adalah disandarkan kepada sanad yang muttasil, memiliki para perawi bersifat `adalah, dan matan 
hadisnya pula tidak mengandungi dari `illah (halangan) dan shadh (keganjilan) (Tahhan 1991:139).

Sebaliknya, silsilah atau sanad tarekat sufi tidak bersifat rigid seperti halnya sanad periwayatan hadis. Sanad dalam tarekat sufi mempunyai dua bentuk. Pertama, sanad yang muttasil atau silsilah muwasalah, yakni berterusan atau bersambungan daripada seorang shaykh kepada seorang shaykh. Kedua, sanad atau silsilah barzakhi, dan juga disebut sebagai silsilah uwaisi (Bruinessen 1996: 49). Sanad barzakhi ini adalah periwayatan seseorang yang masih hidup daripada orang atau shaykh tarekat yang telah wafat melalui mimpi atau jalur lain yang tidak di alam zahir atau pertemuan secara ruhi. Justeru, silsilah barzakhiyyah ini pada zahirnya terlihat mengandungi sanad yang terputus. Oleh kerana itu, sanad barzakhi dikritik, bahkan ditolak oleh banyak pihak justeru terdapat kemungkinan untuk dimanipulasi bagi tujuan 'mensahihkan' sebuah tarekat tertentu. Sebaliknya bagi golongan tasawuf. Sekalipun sanad itu pada zahirnya terputus, kethiqahan sanad barzakhi tidak dipertikaikan apabila seorang shaykh sufi itu merupakan seorang yang thiqah ilmunya, dikenali kesalihannya dan diiktiraf sebagai seorang yang 'arif bi Allah.

Antara contoh berkaitan dengan isu ini adalah sanad tarekat Ahmadiyyah Idrisiyyah yang dinisbahkan kepada Sayyid Ahmad ibn Idris al-Fasi (1757M-1838M). Tarekat ini mempunyai dua jenis sanad atau silsilah. Silsilah pertama adalah silsilah yang guru-murid secara muttasil dan kedua silsilah uwaisiyyah atau barzakhiyyah. Sayyid Ahmad ibn Idris mempunyai sanad muttasil secara bersambung dengan para mashayikhnya daripada tiga tarekat iaitu Tarekat al-Khidriyyah al-'Aziziyah pimpinan Shaykh 'Abd al-Wahhab al-Tazi, Tarekat Sadhiliyyah di bawah asuhan Shaykh Abu al-Qasim al-Waziri al- Ghazi dan Tarekat Khalwatiyyah yang diterima daripada Shaykh Hasan bin Hasan Bek al-Qana`i (Che Zarrina 2000).

Sanad kedua Sayyid Ahmad ibn Idris ialah sanad barzakhi yang merupakan silsilah secara rohani ini merujuk kepada hubungan secara langsung melalui pertemuan suri Sayyid Ahmad bin Idris dengan Rasulullah s.a.w. Silsilah uwaisiyyah ini lebih masyhur penisbahannya kepada Sayyid Ahmad kerana ia memberi kesan rohani yang besar kepada penggembangan kerohanian beliau natijah daripada perjumpaan rohani secara yaqazah dengan Nabi Muhammad SAW. Sanad kedua ini yang banyak digunakan dalam pengamalan Tarekat Ahmadiyyah Idrisiyyah di Malaysia selepas kewafatan Sayyid Ahmad (Faudzinaim et. al. 2021:121; Faudzinaim et. al. 2015). Penggunaan sanad barzakhi ini juga boleh ditemui dalam sanad tarekat Naqshabandiyyah.

Sanad tarekat sufi terjadi disebabkan oleh beberapa perkara iaitu talqin, bay'ah dan suhbah (Abdul Manam 2011; Zakaria 2017). Ketiga tiga perihal tersebut mewujudkan impak keruhanan sehingga terbina sanad tarekat sufi. Hal ini diperkukuhkan oleh kenyataan al-Nazili (t.th.) dengan kaedah "sanad dalam tariqat sufi adalah terbina daripada sandaran perihal kerohanian sepertimana sandaran dalam hukum (isnad al-hal ka isnad al-hukum).

Muhammad Zaki (t.th.) membahagikan sanad kepada tiga jenis iaitu: pertama, sanad al suluk wa al-mujahadah, iaitu sanad asas salik dengan guru murshid yang mentarbiah dirinya kepada Allah. Kedua, sanad al-barakah wa al-tayammun iaitu pengambilan keberkatan daripada sanad tarekat-tarekat yang lain bertujuan untuk mengukuhkan kekuatan kerohanian dengan syarat mendapat keizinan daripada guru yang asal. Ketiga sanad al-suhbah wa al-mubadalah iaitu sanad yang diamalkan oleh para masha'ikh untuk mendapat keizinan saling berkongsi ilmu dan awrad serta rahsia untuk meningkatkan dan memantapkan kerohanian bagi berkhidmat kepada kebenaran.

Kebanyakan sanad tarekat sufi yang diamalkan dalam dunia Islam pada zaman sekarang, termasuk Nusantara, adalah bersambung dengan Nabi Muhammad melalui dua tokoh sahabat besar iaitu Saidina Abu Bakr al-Siddiq (w 634) dan Saidina Ali bin Abi Talib (w 661). Kebanyakan tarekat sufi pada hari ini seperti tarekat Qadiriyyah, Azailiyyah, Samaniyyah, dan Khalwatiyyah mempunyai sanad yang bersambung hingga kepada Nabi Muhammad melalui Saidina `Ali b Abi Talib.

Contohnya, sanad tarekat al-Qadiriyyah adalah `Abd al-Qadir al-Jilani mengambil daripada Abu Sa'ad al-Mubarak al-Makhrumi, daripada Abi al-Hasan Ali bin Ahmad Yusuf alHakari, daripada Abu al-Farj Muhammad bin Abdullah al-Turtusi, daripada Abd al-Wahid bin https://doi.org/10.24035/ijit.20.2021.208 
Abdul Aziz al-Tamimi, daripada Abu Bakar Muhammad Dulf al-Shibli, daripada Abu al-Qasim Junayd al Baghdadi, daripada Abu al-Hasan Al-Sirri bin Muqlas al-Saqati, daripada Abu Mahfuz Ma`ruf bin Fayruz al-Karkhi, daripada Ali al-Rida bin Musa al-Kazim, daripada Musa al Kazim bin Ja`far al-Sadiq, daripada Ja`far al-Sadiq, daripada Muhammad al-Baqir bin Ali, daripada Ali Zainal Abidin bin Husayn, daripada Husayn bin Ali, daripada Ali bin Abi Talib dan daripada Sayyidina Muhammad bin Abdullah(al-Sanusi 1954)

Manakala sanad tarekat Naqshabandiyah pula bersambung dengan Nabi Muhammad SAW melalui Saidina Abu Bakar al-Siddiq. Contoh sanad tarekat Naqshabandiyyah ini ialah: Muhammad Baha' al-Din al-Naqshabandi (w.791H/1389M), daripada al-Amir Kulal (w.772H/1371M), daripada Muhammad Baba al-Samasi (w.740H/1340M), daripada Azizan alNassaj Ramitini (w. 705H/1305M), daripada Mahmud al-Anjiri al-Fanganwi (w.643H/1245M), daripada Muhammad Arif al-Riyakuri Ramitini (w.657H/1259M), daripada 'Abd al-Khaliq alGhajdawani (w.617H/1120M), daripada Abu al-Abbas Saydina Khaidir A.S., daripada Sayyidina Abu Ya`kub Yusuf al-Hamadani (w.535H/1140M), daripada Abu Ali al-Fadl al-Farmadhi (w. 477H/1084M), daripada Abu al-Hasan al-Kharkhani (w.425H/1034M), daripada Abu Yazid alBistami (w.260H/874M), daripada Ja`far al-Sadiq bin Muhammad al-Baqir (w.148H/765M), daripada Qasim bin Muhammad bin Abu Bakar (d.107H)/725M), daripada Salman al-Farisi (w.33H/654M), daripada Sayyidina Abu Bakar al-Siddiq (w.13H/634M) dan daripada Sayyidina Muhammad SAW (w.11H/632M). Namun begitu terdapat juga sanad dalam tareqat Naqshabandiyah melalui Ali b Abi Talib yang dinamakan sebagai rangkaian emas (silsilah aldhahabiyyah) (al-Sanusi 1954).

Berdasarkan perbincangan di atas, kedudukan sanad atau silsilah tarekat sufi tidak bertentangan dengan ajaran Islam. Tradisi sanad atau silsilah atau nisbah yang diwarisi dalam institusi tarekat adalah sandaran pengukuhan kepercayaan ilmu dan amalan kerohanian berasal daripada perjalanan para sahabat dan sunnah Rasulullah. Para shuyukh tarekat sufi yang mempunyai sanad sufi yang sahih adalah diakui keilmuan mereka dan mempunyai kelayakan untuk memberikan tarbiyah ruhiyyah kepada para pengikut mereka.

\section{Peranan Sanad dalam Tarekat sufi}

Sanad adalah suatu asas penting dalam sebuah tarekat tasawuf kerana ia menghubungkan syeikh tarekat semasa dalam suatu jaringan atau silsilah masha ikh sebelumnya bagi sesebuah tarekat. Hubungan rantaian dengan para masha ikh tersebut menjadi bukti kepada keautoritian seorang syeikh tarekat bagi membawa, mengajar dan menyebar tarekat yang diizinkan kepadanya. Tanpa sanad yang benar dan sahih, sesebuah tarekat itu tidak dikira sah di sisi ahli tarekat. Ia merupakan saluran pengaliran keberkatan kerohanian daripada Nabi Muhammad. Ia mempunyai hubungan yang amat erat dengan beberapa elemen penting dalam tarekat tasawuf seperti saluran pengaliran keberkatan kerohanian daripada Nabi Muhammad, mempunyai pengaruh dalam proses tazkiyat al-nafs (penyucian jiwa), peningkatan maqamat dan keizinan penyebaran sesebuah tarekat. Oleh kerana kepentingan kedudukan sanad dalam tarekat sufi, para masha'ikh tasawuf sangat menjaga kesahihan sanad kerana peranannya yang besar.

Antara peranan sanad tarekat sufi yang paling dasar ialah ia merupakan asas kepada kemuktabaran sesebuah tarekat sufi. Dalam tradisi tarekat tasawuf, seorang itu dianggap shaykh murshid apabila ia telah mencapai maqam tarbiyyah dan mendapat keizinan dari gurunya untuk menjalankan tugas tarbiyah. Satu lagi syarat penting kepada pengiktirafan seorang shaykh murshid ialah mempunyai sanad atau silsilah yang benar serta bersambung hingga kepada Nabi Muhammad. Di dalam Khazinat al-Asrar, al-Nazili (w.1884M) menegaskan: "Sesiapa mengamalkan amalan tarekat dan tidak bersambung sanad gurunya kepada Rasulullah, maka amalannya tidak akan memperoleh anugerah dan keberkatan daripada Nabi Muhammad dan rahsia cahaya Allah. Orang tersebut juga tidak mendapat warisan daripada Nabi Muhammad SAW hingga dia tidak berhak menjadi guru mursyid, tidak berhak memberikan baiah dan memberikan ijazah kepada orang lain" (al-Nazili t.th: 188). 
Sanad menjadi tanda kebenaran atau keizinan untuk mengajar dan memberi tarbiah. Perkara ini adalah berdasarkan ijazah yang diberikan oleh seorang guru mursyid kepada muridnya. Ijazah ini adalah suatu pengakuan bertulis, yakni taqrir, daripada seorang shaykh murshid kepada muridnya yang berkelayakan untuk untuk mengajar dan memberikan tarbiyah rohaniah kepada orang lain. Isi kandungan ijazah khusus ini mengandungi beberapa elemen utama iaitu wasiat shaykh kepada muridnya, sanad atau silsilah perguruan hingga kepada Nabi Muhammad, catatan tarikh, tanda tangan serta cop mohor shaykh murshid tersebut.

Dengan catitan demikian, ijazah yang diberikan kepada seorang murid itu mempunyai tiga fungsi utama. Pertama, pengakuan daripada guru mursyid berhubung kelayakan muridnya itu untuk berkhidmat dan menggembangkan tarekat gurunya. Kedua, pembuktian kesahihan dan kelayakan seorang murid itu untuk menjadi wakil guru dan tarekatnya untuk memberikan tarbiyah kepada orang lain. Ketiga, ijazah yang sahih itu menjadi sumber keberkatan dalam amalan yang disebarkan oleh seorang guru tarekat sufi. Amalan pemberian ijazah rasmi dalam tarekat sufi ini adalah suatu kaedah yang dapat mengelak daripada berlaku penyelewenagn dan dakwaan palsu sebagai guru mursyid daripada individu yang tidak bertanggung jawab (Muhammad Zaki t.th).

Seterusnya, sanad tarekat sufi adalah asas yang menjadi bukti kesahihan amalan seorang salik yang telah menerima talqin zikir daripada gurunya. Perkara ini adalah penting kerana amalan zikir yang diambil dan diijazahkan oleh guru mempunyai kesan yang besar kepada penyucian hati dan meningkatkan ketaatan dan makrifah kepada Allah. Amalan zikir yang diperolehi daripada shaykh murshid yang mempunyai sanad yang sahih diistilahkan sebagai zikir darajat yang boleh memberi manfaat kepada penyucian jiwa dan peningkatan maqamat di sisi Allah. Sebaliknya, amalan zikir yang tidak diambil daripada lisan guru murshid hanya bersifat zikir hasanat di mana orang yang melakukan amalan zikir itu mendapat pahala kebajikan sahaja dan penyucian jiwa sahaja (Thahirah et. al. 2014).

Perkara ini pada hakikat adalah mengambil iktibar daripada perjalanan para sahabat yang telah menerima talqin zikir daripada Nabi Muhammad seperti yang dicatatkan dalam beberapa keterangan yang melibatkan para Sabahat seperti Saidina Abu Bakar dan Saidina `Ali Bin Abi Talib. Qaylubi (2002) dan al-Sha'rani (2004) menjelaskan bahawa Rasullullah telah mentalqinkan Abu Bakar al-Siddiq dengan zikir Ism Allah dengan secara sirr di dalam hati sehinggalah kalimah Allah sentiasa berdetik di dalam hati. Saidina `Ali bin Abi Talib juga telah menerima talqin zikir daripada Nabi Muhammad. Sayyidina `Ali berkata: Wahai Rasulullah, tunjukkan kepada sedekat-dekat jalan kepada Allah ta`ala dan paling mudah ke atas hamba-Nya dan paling utama di sisi Allah. Maka Rasulullah bersabda: Wahai'Ali, hendaklah engkau sentiasa berzikir kepada Allah ta`ala dalam keadaan kamu sendirian. Maka `Ali pun berkata: Bagaimanakah hendak aku berzikir wahai Rasulullah? Maka Rasulullah pun bersabda: Tutupkan kedua mata mu, dan dengari daripada aku tiga kali. Maka Rasulullah s.a.w pun membaca: La ilaha Illa Allah tiga kali. Dan Sayyidina `Ali pun mendengar daripada baginda s.a.w dan membaca, "La ilaha illa Allah" tiga kali dan Nabi pula mendengarnya (Ibn `Aqilah 2000: 87). Saidina Ali bin Abi Talib kemudiannya telah mentalqinkan Hasan al-Basri dengan zikir tersebut dan seterusnya kepada Habib ibn Muhammad al-'Ajami al-Basri (w 772), Abu Sulaiman Dawud ibn Nasir al-Ta'I (w. 781), dan Abu Mahfuz Ma'ruf Ibn Firuz al-Karkhi (w815) (Qaylubi 2002; al-Sha'rani 2004)

Selain itu, sanad juga menjadi pengesahan kebenaran suhbah dengan guru melalui amalan melihat, bermuamalah dan kasih kepada guru dalam pentarbiyahan. Suhbah adalah amalan para sahabat untuk mendapat kekuatan kerohanian. Keimanan para sahabat menjadi kukuh kerana mereka memperolehi iman shuhudi iaitu iman melalui perdampingan dan mulazamah dengan Rasulullah. Suhbah dapat memindah cahaya kerohanian melalui penglihatan yang disertai dengan keimanan dan kasih kepada guru yang bersambung nisbah kerohaniannya kepada Nabi. Ketika suhbah inilah terjadinya proses ta lim, tarbiyyah dan tarqiyyah yang boleh memberikan pengukuhan iman dan amalan seorang salik kepada Allah melalui bimbangan guru. Berdasarkan pengalaman para masha'ikh tarekat sufi, suhbah sesaat bersama shaykh murshid menyamai kelebihan amalan satu kali khalwah empat puluh hari yang dilakukan oleh seorang salik (alQazani t.th; Wan Sulaiman 1337H). Hal ini adalah disebabkan kesan keberkatan daripada https://doi.org/10.24035/ijit.20.2021.208 
bersuhbah dengan guru mursyid dalam konteks peningkatan ilmu dan ilmu dan ingatan kepada Allah. Kesan suhbah inilah yang diisyaratkan dalam sebuah hadis Nabi yang bermaksud "Sebaikbaik kamu ialah apabila mereka itu dilihat membawa hati mengingati Allah" (al-Haithami t.th, 10:226)

Al-Sirhindi (t. th.) juga turut memperakukan kelebihan suhbah dengan katanya: "Maka sesungguhnya, para Sahabat RA, pada awal suhbah dengan Nabi telah mendapat apa yang tidak boleh dicapai di peringkat pengakhiran Awliya' Ummah selain mereka. Dengan sebab itulah, walaupun Uwais al-Qarni merupakan sebaik-baik tabi'in, beliau tidak dapat menyamai martabat Wahshi yang telah membunuh Hamzah RA kerana beliau telah melihat wajah Rasulullah walaupun sekali ketika memeluk Islam. Maka kelebihan bersuhbah menurut golongan sufi adalah tinggi, melampaui semua kelebihan dan kesempurnaan. Justeru iman para sahabat adalah iman yang bersifat shuhud dan mencapai maqam wilayah yang sukar diperolehi oleh orang selain mereka."

Penghayatan amalan suhbah juga dapat membantu salik untuk menyingkir ingatan hatinya terhadap makhluk supaya hatinya hanya tertumpu kepada Allah. Dalam konteks tarekat sufi, rasa hudur al-qalb ma'a Allah itu akan dapat dilatih dan dicapai dengan cara bersuhbah dengan shaykh murshid dalam perhimpunan majlis zikir bersamanya, mendengar pengajarannya. Dengan cara tersebut, para masha'ikh sufi menegaskan bahawa suhbah dapat meningkatkan keyakinan hati dan memberi manfaat kepada salik dalam mengamalkan syariat Islam. Perhubungan secara ruhi dengan shaykh murshid melalui suhbah itu akan berterusan di luar majlis zikir secara jama $i$ itu melalui amalan zikir yang dilakukan oleh salik secara bersendirian (Isa t. th: 58-59)

Seterusnya sanad juga berfungsi sebagai bukti kebenaran penerimaan bay'ah (penjanjian) seorang salik dengan guru untuk taat kepada Allah. Perjanjian dalam tarekat sufi ini merujuk kepada perjanjian taubat (bay'at tawbah) dan perjanjian kuatkan azam (bay'ah al-ta'kid al-'azimah) untuk sentiasa patuh dan istiqamah dalam mengamalkan segala titah perintah Allah dan Rasul secara 'azimah dan tekun (Muhammad As'ad 1334H). Dalam nada yang sama, alKandahlawi (1976) juga menjelaskan bahawa perjanjian dalam tarekat sufi tidak merujuk kepada perjanjian memeluk Islam atau berjihad. Sebaliknya, baiat dalam tarekat sufi adalah satu ikrar salik untuk memperteguhkan niat dan kesungguhannya pelaksanaan hukum-hakam Islam.

Amalan bay'ah dalam tarekat sufi adalah termasuk dalam amalan sunnah dan bukan bidaah. Muhammed ibn al-Hajj al-Abdari al-Fasi menyatakan bahawa mengambil bay'ah bukan daripada perbuatan bidaah. Sebaliknya, amalan ini adalah termasuk usaha menghidupkan sunnah Rasulullah. Nabi sendiri pernah mengambil perjanjian daripada para sahabat dengan pelbagai tujuan seperti perjanjian untuk taat, tidak syirik kepada Allah, tidak mencuri, tidak membunuh dan tidak membuat fitnah dan sebagainya (Abu Zahrah 2002). Perkara ini juga jelas disebutkan oleh Allah dalam firman-Nya yang bermaksud: "Sesungguhnya orang-orang yang memberi pengakuan taat setia kepadamu (Wahai Muhammad - untuk berjuang menentang musuh), mereka hanyasanya memberikan pengakuan taat setia kepada Allah; Allah mengawasi keadaan mereka memberikan taat setia itu (untuk membalasnya). Oleh itu, sesiapa yang tidak menyempurnakan janji setianya maka bahaya tidak menyempurnakan itu hanya menimpa dirinya; dan sesiapa yang menyempurnakan apa yang telah dijanjikannya kepada Allah, maka Allah akan memberi kepadanya pahala Yang besar (al-Quran, al-Fath 48: 10).

Perkara yang sama juga disebutkan oleh Allah dalam surah al-Mumtahanah, ayat 12 yang bermaksud: "Wahai Nabi! apabila orang-orang perempuan yang beriman datang kepadamu untuk memberi pengakuan taat setia, Bahawa mereka tidak akan melakukan syirik kepada Allah Dengan sesuatu pun, dan mereka tidak akan mencuri, dan mereka tidak akan berzina, dan mereka tidak akan membunuh anak-anaknya, dan mereka tidak akan melakukan sesuatu perkara dusta Yang mereka ada-adakan dari kemahuan hati mereka, dan mereka tidak akan menderhaka kepadamu Dalam sesuatu perkara Yang baik, - maka Terimalah pengakuan taat setia mereka dan pohonkanlah kepada Allah mengampuni dosa mereka; Sesungguhnya Allah Maha Pengampun, lagi Maha Mengasihani." 
Begitu juga Hadis yang merekodkan perbuatan baiah yang dilakukan oleh Nabi Muhammad bersama dengan para Sahabat daripada kalangan muslimin dan muslimat. Rasulullah bersabda ketika berada di tengah-tengah sebahagian sahabat: "Berbaiahlah kalian kepadaku untuk tidak menyekutukan Allah dengan sesuatu apapun, tidak mencuri, tidak berzina, tidak membunuh anak-anak kalian, tidak membuat kebohongan yang kalian ada-adakan antara tangan dan kaki kalian, tidak bermaksiat dalam perkara yang makruf. Barangsiapa antara kalian yang memenuhinya maka pahalanya ada pada Allah dan barangsiapa yang melanggar dari hal tersebut, lalu Allah menghukumnya di dunia, maka itu adalah kafarah baginya, dan barangsiapa yang melanggar dari hal-hal tersebut kemudian Allah menutupinya (tidak menghukumnya di dunia) maka urusannya kembali kepada Allah. Jika Dia mahu, dimaafkannya atau disiksanya. Maka kami membaiat baginda untuk perkara-perkara tersebut. (al-Bukhari, Sahih al-Bukhari. Kitab al-Iman, Bab 'Alamat al-Iman Hubb al-'Ansar. No 17).

Sanad tarekat juga berperanan sebagai wasilah untuk mendapat pertolongan dan bantuan daripada Allah. Hal ini adalah merujuk kepada amalan menghadiahkan pahala bacaan ayat-ayat al-Quran, selawat dan zikir kepada mash'aikh tarekat yang bersambung sehingga kepada Nabi. Amalan ini adalah termasuk di bawah amalan tawassul yang amalkan sebagai $a s b a b$ untuk mendapat pertolongan dan limpahan barakah mereka kepada salik dengan izin Allah dan sebab yang membawa kepada turunnya rahmat Allah dan dan kasih-Nya. Perkara ini sesuai dengan firman Allah bermaksud: Wahai orang-orang yang beriman! Bertakwalah kepada Allah dan carilah wasilah (jalan) untuk mendekatkan diri kepada-Nya, dan berjihadlah (berjuanglah) di jalan-Nya, agar kamu beruntung." (Al-Maidah, 5: 35) dan hadis Rasulullah bahawa Menyebut para salihin adalah sebab turunnya rahmat daripada Allah (Abu Na'im al-Asbahani.Hilyat alAuliya wa Tabaqat al-Asfiya'. Justeru Abu Said Muhammad al-Khadimi menyatakan bahawa orang yang membaca silsilah masha'ikh selepas daripada sempurnanya amalan khatam khawjakan dan talqin zikir, maka dia akan memperolehi peningkatan kerohanian dan pembukaan matahati, dapat menolak kesusahan, dan kesedihan, mendapat kelapangan hidup, memudahkan urusun, menunaikan hajat, kesembuhan penyakit dan lain lain (al-Nazili t.th.; al- Kurdi 1994).

Perkara ini adalah termasuk di bawah karamah dan kurniaan Allah kepada para awliya'Nya semasa hidup dan mati meraka. Pertolongan mereka di alam barzakh kepada orang yang masih hidup adalah perkara mumkin daripada aspek aqidah dengan izin serta kurniaan Allah. Kematian bukanlah bermakna binasa roh manusia tetapi sebagai proses perpindahan hidup dari alam dunia yang bersifat jasadiah ke alam barzakh yang bersifat rohaniyyah. Mengenai perkara ini jelas, Ibn Qayyim (2002) menyatakan di dalam karyanya, al-Ruh bahawa sesungguhnya telah mutawatir mimpi dan riwayat-riwayat bahawa ahli kubur (daripada para wali Allah) mempunyai kekuatan (yang diberikan oleh Allah melalui kurniaanNya) di alam barzakh untuk mengurus (hal ehwal kehidupan) dengan keadaan lebih kuat daripada keadaan semasa mereka masih hidup di dunia kerana roh telah bebas daripada ikatan-ikatan yang bersifat badaniah jasmaniyyah.

Perkara ini juga ditegaskan oleh Imam Ahmad bin Muhammad Sharif al-Hamawi dalam kitabnya Nafahat al-Qurb wa al-Ittisal bi Isbat al-Tasarruf li Awliya'Allah wa al-Karamat Ba'd alIntiqal menulis: Para wali Allah diberi kemampuan (oleh Allah) boleh menzahirkan pelbagai rupa mereka (dengan izin Allah) disebabkan oleh kekuatan rohani mereka yang melampaui dan mengatasi atas hal jasad mereka. Begitu juga dengan Imam al-Jurjani di dalam Sharh al-Mawaqif menulis: "Boleh bagi para Auliya' Allah menzahirkan pelbagai keadaan rupa mereka kepada para murid dan mereka (para murid) boleh mengambil pancaran limpahan rohani daripada mereka (para auliya) walaupun selepas kematian mereka (Abu Zahrah 2002).

Al-Kurdi (1994) juga turut menyatakan perkara yang sama di dalam Tanwir al-Qulub dengan katanya: "Adapun kemampuan orang mati dan pekerjaan yang terbit daripada mereka adalah dengan qudrah (kuasa) Allah. Ini bertepatan dengan sebuah riwayat Ibn 'Adi daripada Rasulullah yang mengatakan selepas kematian Ja'far RA: “Aku mengetahui bahawa Ja'far berada bersama sebahagian para malaikat yang sedang memberi berita gembira kepada penduduk Bishah (sebuah negeri di Yaman) mengenai turunnya hujan." Namun demikian, amalan bertawasul dengan para masa'ikh dalam sanad tarekat perlu dipahami dengan iktikad yang sahih. 
Para masha'ikh dalam silsilah tarekat, sama ada yang hidup atau yang telah mati, hanyalah sebagai sebab majazi sahaja. Pada hakikatnya, segala kesan pemberian, limpahan, manfaat dan mudarat adalah datang daripada Allah dan terjadi dengan kehendak dan izin-Nya semata-mata.

Perbincangan di atas menunjukkan sanad tarekat sufi adalah berasal daripada tradisi Islam. Ia memiliki nilai agama Islam yang bersifat autoritatif yang tidak dapat disangkal. Kedudukan dan peranan sanad tarekat sufi adalah penting dan jelas dalam ilmu tasawuf. Sama ada ia dikenali sebagai sanad atau silsilah atau nisbah, ia bukanlah rekaan para masha'ikh tarekat sufi. Kedudukan sanad tarekat adalah sebagaimana sanad ilmu-ilmu agama yang lain sama ada dalam bidang akidah, fekah, qira'at dan sebagainya. Sanad merupakan keistimewaan yang wujud bagi umat nabi Muhammad selari dengan perkembangan dan pengkukuhan kesahihan ilmu-ilmu Islam yang lain.

Al-Quran.

\section{References}

Abdul Manam bin Mohamad. 2011. Silsilah Dalam Ilmu Tarekat. Prosiding Diskusi Tarekat Tasawuf Negeri Sembilan 2011. Negeri Sembilan: Jabatan Mufti Kerajaan Negeri Sembilan.

Ahmad Warson Munawwir. 1997. Al-Munawwir Kamus Arab-Indonesia. Tahqiq Ali Ma'shum \& Zainal Abidin Munawwair. Pustaka Progessif: Yogjakarta.

al-Asfahani, Ahmad b. 'Abd Allah Abu Nu`aym. 1988. Hilyat al-Awliya' wa Tabaqat al-Asfiya'. Beirut: Dar al-Kitab al-'Ilmiyyah.

Bruinessen, Martin V. 1996. Tarekat Naqsyabandiyah di Indonesia. Cet.4. Bandung: Mizan.

al-Bukhari, Abu `Abd Allah Muhammad bin Isma`il. 2002. Sahih al-Bukhari. Dimashq: Dar Ibn Kathir.

Che Zarrina Saari. 2000. Biografi Shaikh Ahmad B. Idris dan sumbangannya terhadap alam kesufian. Al-Afkar. No. 1(June): 33-54.

Al-Falimbani, Abd al-Samad. Siyar al-Salikin. t.th. Thailand: Maktabah Muhammad Nahdi wa Awladuhu.

Al Fasi, Abi Abdullah b Muhammad Saghir 2005. al Manh al-Badiyah fi al-Asanid al-Aliyyah wa alMusalsalat al-Zahiyah wa al-Turuq al-Hadiyah al-Kafiyyah. Maghribi: Wizarah al-Awqaf wa li Shu'un al -Islamiyyah.

Faudzinaim Bin Badaruddin, Zakaria Stapa, Abdull Rahman Mahmood \& Mohd Khairi Mahyuddin. 2021. Tarekat Ahmad B. Idris Al-Fasi dan pengaruhnya di Malaysia. Akademika. 91 (1):119127.

Faudzinaim Bin Badaruddin, Zakaria Stapa, Abdull Rahman Mahmood, Muhammad Khairi Mahyuddin \& Nozira Salleh. 2015. Kajian Tarekat Ahmadiyyah Idrisiyah: Kajian Perkembangan Dan Amalannya di Malaysia. Putrajaya: Jakim.

Al-Haithami, Nur al-Din `Ali bin Abi Bakr. t.th. Majma`al-Zawa'id wa Manba`al-Fawa'id. 10 Jil. Bayrut: Dar al-Ma'mun li Turath.

Al-Husaini, Abu Zahra’ Uwais bin `Abd Allah al-Mujtabi. 2002. al-Isharat al-Sunniyyah li Salikiy alTarekat al-Naqshabandiyyah. t.tp.: Dar al-Mustafa

Ibn `Aqilah, Muhammad b. Ahmad b. Sa`id al-Hanafi al-Makki. 2000. Fawa'id al-Jalilah fi Musalsalat Ibn `Aqilah. Tahqiq wa Ta’liq. Muhammad Rida. Beirut: al-Basha'ir al-Islamiyyah.

Ibn Qayyim, Muhammad bin Abi Bakar. 2002. Al-Ruh. Beirut: Dar al-Fikr.

Ibrahim, Muhammad Zaki. t.th. Ijazah Muhammadiah Sufiyyah Salafiyyah Izn Shar' Islamiyy bi alDa'wah al-Islamiyyah. t.p: Qahirah

Imran Abu Amar.1980. Sekitar Tariqat Naqsyabandiyah. Jakarta: Menara Kudus.

'Isa, `Abd al-Qadir. t.th. Haqa'iq 'an al-Tasawwuf. Norwich: Diwan Press.

Jahid Sidek. 1991. Shaikh Dalam Ilmu Tarekat. Kuala Lumpur: Penerbit Universiti Malaya.

Al-Jurjani, al-Sayyid `Ali ibn Muhammad. 1938. Al-Ta'rifat. Qahirah: Maktabah wa Matba`ah Mustafa al-Babi al-Halabi wa Awladihi.

Kamus Dewan. 2015. Dewan Bahasa dan Pustaka. Edisi Keempat. Kuala Lumpur: Dewan Bahasa dan Pustaka.

Al-Kandahlawi, Muhammad Zakariyya. 1339H. al-Shari'ah wa al-Tariqah. Cairo: Dar al-Rashid. 
al-Kurdi, Muhammad Amin. 1994. Tanwir al-Qulub fi Mu'amalah 'Allam al-Ghuyub. Beirut: Dar alFikr.

al-Marbawi, Muhamad Idris. 1994. Kamus Idris al-Marbawi. Dar al-Nu'aman: Kuala Lumpur.

Moh Ison Mudin. 2015. Suhbah: relasi mursyid dan murid dalam pendidikan spiritual tarekat. Tsaqafah. Jurnal Peradaban Islam. Jil. 11 (2) November: 399-416.

al-Nazili, Muhammad Haqqi. t.th. Khazinah al-Asrar Jalilah al-Adhkar. t.tp.: Maktabah wa Matbacah Taha Putra Semarang.

Al-Qashani, `Abd al-Razzaq. 1991. Kitab Istalahat al-Sufiyyah. (Sufi Technical Terms).Trans. Nabil Safwat.. London: The Octagon Press Ltd.

al-Qazani, Muhammad Murad Abdullah. t.th. Kitab Tarjamah Rashahat cayn al-Hayat al-Asli li alShaykh al- 'Arif billah `Ali b Husain al-Wa iz al-Kashifi al-Harawi. T.tp: t.p.

al-Qaylubi, Abd Rabbuh b Sulaiman. 2002. Fayd al-Wahhab fi Bayan Ahl al-Haq wa Man Dalla 'an al-Sawab. Misr: Maktabah Qaherah.

Sa'ad, Qasim Ali. 2010. Qimat al-Isnad. Bayrut: Dar al-Baha'ir al-Islamiyyah.

al-Sanusi, al-Sayyid Muhammad bin Ali al al-Sanusi. 1954. al-Manhal al-Rawi al-Ra'iq fi Asanid alUlum wa Usul al-Tara'iq. Matba'ah Hijazi: Qaherah.

al-Sha`rani, 'Abd al-Wahhab Ahmad. 2004. Al-Anwar al-Qudsiyyah fi Bayan Qawa`id al-Sufiyyah. Beirut: Dar Sadir.

al-Sha`rani, `Abd al-Wahab Ahmad. t.th. Al-Tabaqat al-Kubra al-Musamma bi Lawaqih al-Anwar fi al-Tabaqat al-Akhyar. Beirut: Dar al-Fikr.

al-Sirhindi, Ahmad Abdul Ahad. t.th. Al-Maktubat li al-Imam al-'Alim al-Rabbani al-Mujaddid li alfi al-Thani Ahmad al-Faruqi Al-Sirhindi. Mu`arrab al-Maktubat al-Shari ah al-Marsum bi alDurr al-Maknunat al-Nafisah. Trans. Muhammad Murad al-Qazani. Istanbul: Siraj Kitabevi.

Tahhan, Mahmud. 1991. Ushul al-Takhrij wa Dirasah al-Asanid. Cet. iii. Riyadh: Maktabah alMa'arif.

Thahirah Hassan Basri, Faudzinaim Badaruddin dan Abdul Manam Mohamad. 2014. Konsep zikir darajah dalam disiplin ilmu tarekat. Jurnal Islam dan Masyarakat Kontemporari. Bil. 8 (Jun): 61-72.

Wan Saleha Wan Sayed, Mohd Hashrul Shuhari dan Wan Hishamuddin Wan Jusoh. 2020. Institusi tarekat tasawuf dalam pemantapan spiritual insan. Malaysian Journal for Islamic Studies. 4 (2): 55-66.

Wan Sulaiman Wan Siddik. 1337H. Inilah Risalah Bernama Nihayah al-Matlub li Tasfiyyah alQulub. Pulau Pinang: Persama Press

Wan Sulaiman Wan Siddik. 1343H. Futuhat Qadahiyyah fi Bayan Haqiqah al-Tarekat alNaqshabandiyyah al-Mujaddidiyyah al-Ahmadiyyah al-Mutabaqah Li al-'Ulum al-'Asriyyah. . Pulau Pinang: Mercantile Press.

Wan Sulaiman Wan Sidek. 1352H. Mizan al-Uqala' wa al-Udaba' Iaitu Pada Menyatakan Makna Shariat, Tarekat, Hakikat, dan Makrifat. Penang: Matba`ah United Dato Keramat Road.

Zaidan, `Abd al-Karim. 2008. 'Ulum al-Hadith. Beirut: Mu'assasah Risalah al-Nashirun. 